\title{
The Influence of Knowledge, Compensation for Documentation Upbringing Treatment through Motivation Nurse in Mamuju Regional General Hospital
}

\author{
Sultan, Hasmin Tamsah and Hasan Nongkeng \\ Sekolah Tinggi Ilmu Ekonomi AMKOP Makassar, Indonesia \\ sultanholamuhamma@gmail.com, hasmin@stieamkop.ac.id, hasan.nongkeng@yahoo.com
}

\author{
Jumra \\ Sekolah Tinggi Ilmu Hukum Pengayoman, Makassar, Indonesia \\ jumrajumra@gmail.com
}

Yusriadi Yusriadi

Sekolah Tinggi Ilmu Administrasi Puangrimaggalatung, Makassar, Indonesia

yusriadi.yusriadi@uqconnect.edu.au

Loth Botahala

Universitas Tribuana Kalabahi

botahala@gmail.com

M Chairul Basrun Umanailo

Universitas Iqra Buru

chairulbasrun@gmail.com

\begin{abstract}
This study aims to know (1) The direct influence of Knowledge, Compensation on motivation, (2) The direct influence of Knowledge, Compensation, and motivation on documentation, (3) The Effect of Knowledge, Compensation on documentation through motivation. This research was conducted at the Mamuju Regional General Hospital from 15 September to 15 October 2019. This type of analysis used a quantitative study by using a descriptive design with a path analyst approach. This study's sample was all nurses who documented nursing care and had a minimum education of D3 Nursing, totaling 147 respondents with total sampling. Data was taken by using a questionnaire. This research concludes that there is a direct effect of Knowledge and compensation on motivation, the immediate effect of Knowledge, reward, motivation on documentation, and the indirect impact of the experience, payment on documentation through motivation.
\end{abstract}

Keywords:

Knowledge, Compensation, Documentation, and Motivation

\section{Introduction}

In Indonesia, the practice of temporary nursing is a process of professionalism in which developments and changes occur globally and locally. Often, the problem faced in the execution of treatment upbringing in this state is that there are still many nurses who have not performed nursing services according to nursing care standards. The implementation of nursing care is also not accompanied by complete documentation (Asmadi, 2008).

Documenting nursing care is a record of the patient's response to implementing nursing care, systematically and structured as accountability for the patient's actions in carrying out nursing care using the approach of the nursing care 
process (Prabowo, 2016). If documentation conducted by at treatment upbringing is not carried out, it will reduce the quality of nursing services. It will not be able to identify the extent of nursing care's success that has been given. In legal aspects, nurses do not have written evidence if they demand dissatisfaction with nursing services (Yanti, 2013). In the hospital, it is found that documentation of nursing care is incomplete for several reasons, such as not all nurses in service institutions have the same knowledge and abilities. Not all nurses in service institutions have the same experience and skills. Nursing staff comes from different levels of education and inadequate compensation (Ehrenberg \& Birgersson, 2003). According to Rivera \& Parris (2002), nurses have difficulty diagnosing, and the diagnosis is not based on causative factors. Nursing care documentation must be filled in completely to achieve maximum patient health status.

Ehrenberg's research, Ehnfors \& Ekman (2004) have shown a severe lack of health records or nursing care documentation. These deficiencies, such as information that is not specific and data, are often lacking. Studies show a lack of completeness in the records that can hamper the nursing care process's picture. Nurse education influences nurses' performance because the higher the education, the more knowledge and skills are possessed to improve performance quality, especially in documenting nursing care (Delaney et al., 2000; Mu'adi et al., 2020; Nawawi et al., 2020). Nurse motivation is an encouragement for a nurse to work diligently and competently by the duties and obligations that have been given to him and is an essential professional for a new job. Nurse motivation is necessary because, with motivation, nurses will be more eager to carry out the assigned tasks and improve the quality of nursing care. Compensation is indirect to direct appreciation or earnings that a nurse accepts as the reward of its service, which in the form of goods or money to the hospital because the nurse has contributed energy and thoughts for the hospital's progress to achieve the stated goals.

Knowledge is the result of "knowing," which happens after people have sensed a specific object. Knowledge of the implementation of documentation must be possessed by various health professionals, including a nurse. A nurse has a role in carrying out nursing care documentation in the medical record (Damayanti, 2013; Nuraini et al., 2019; Umanailo, 2020, 2019). Based on data obtained from the Mamuju District General Hospital's nursing quality team in 2018 , the percentage of completeness of nursing care documentation for nursing assessment is $51 \%$, nursing diagnosis $51.2 \%$, intervention $59 \%$, implementation $50 \%$, nursing evaluation $50 \%$. The average result is $52.24 \%$. The results of observations, implementation of nursing care documentation was carried out by nurses with completing the format of assessment, diagnosis, intervention, performance, and evaluation of nursing.

\section{Literature Review}

\subsection{Nursing Care Documentation}

Documentation is everything written or printed by authorized individuals. Records must describe the patient's care, the status, and needs of the comprehensive patient (Potter \& Perry). While Fisbach states, the documentation is written information about the status and development of the patient's health condition and all nursing care activities carried out by the nurse. Documentation is a document that contains complete, accurate, and recorded data about the patient's level of pain and the type and quality of service. In implementing nursing care documentation, nurses must follow several nursing care documentation stages as an indicator of documentation. Nursing care is a process or series of activities on nursing practice that is given directly to patients based on the rules of nursing as a profession based on nursing knowledge and tips, are humanistic, and based on the patient's objective needs to overcome the problems faced by patients, stages of documentation of nursing care, namely: Assessment, Nursing Diagnosis, Nursing Interventions, Nursing Implementation, and Evaluation.

\subsection{Knowledge}

The knowledge covered in the cognitive domain has six levels, namely:

(1) Knowing is interpreted as remembering a material that has been studied previously, (2) Understanding is interpreted as an ability to explain correctly, (3) objects that are known and can interpret the material perfectly, (4) Application is interpreted as the ability to use a material that has been studied in real situations or consolidation (actually), (5) Analysis is the ability to describe a material or object into components, (6) It still within the organizational structure, and there is always a connection with each other, and (7) Synthesis shows the ability to carry out or connect parts of a new whole form. This evaluation relates to the ability to justify or evaluate a material or object. The indicators used in this study is to adapt the theory that is divided as follows: Suitability of the employee's educational background with work, employee's knowledge of the procedures for carrying out his duties, employee's 
understanding of the procedures for carrying out his duties, work experience owned by employees, work performance owned by employees.

\subsection{Compensation}

Employees who work in an organization need compensation or compensation that is sufficient and fair, even if it can be competitive enough compared to other organizations or companies. A sound compensation system will significantly affect one's spirit at work and productivity. According to Simamora (2004), indicators to measure employee compensation include wages and salaries, incentives, benefits, and facilities.

\subsection{Motivation}

Motivation comes from the Latin word move, which means encouragement or move. Motivation is the impetus for a series of human behavior processes to achieve goals. Simultaneously, the elements in motivation consist of aspects of arousing, directing, maintaining, showing intensity, being continuous and purposeful. According to Hasibuan (2017), employee motivation is influenced by or indicators to determine the level of work motivation in employees: the need for achievement, the need for affiliation, the need for competence, and the need for power.

\section{Methods}

This research is studied quantitatively, which approach of path analysis, where an independent variable, intervening variable, and dependent variable are conducted by measurement concurrently. The study was conducted on nurses at the Mamuju Regional General Hospital. Data collection techniques were in this research by distributing questionnaires of the responder. In this study, the sample used was a total sample of all nurses documenting nursing care in Mamuju Regional General Hospital. As many as 147 people who met the inclusion criteria, namely nurses willing to be respondents, had a minimum education of D3 and carried out nursing care documentation.

The variables in this study were measured using a scale range of $1-5$ where the number 1 (one) indicates the sting of disagreeing and the scale of 5 (five) shows strongly agree with the statement in the questionnaire. The statements in the questionnaire were built from several concepts and results of previous studies. Documentation is everything written or printed by authorized individuals. Records must describe the patient's care, the status, and the needs of the patient comprehensively. In implementing nursing care documentation, nurses must follow several nursing care documentation stages as an indicator of documentation. (1) Assessment, (2) Nursing diagnoses, (3) Nursing interventions, (4) Implementation of nursing, and (5) Evaluation.

Knowledge includes cover in the cognate area with six levels: Know, Application, Analysis, Synthesis, Evaluation. Indicators used in this study adapt theories that are divided as follows:

a. Suitability of employee education background with work

b. Employee knowledge of the task implementation procedures

c. Understanding of employees about the methods for carrying out their duties

d. Work experience owned by employees

e. Work performance owned by employees

Employees who work in an organization need compensation or compensation that is sufficient and fair, even if it can be competitive enough compared to other organizations or companies. According to Simamora (2004), employee compensation can be measured with indicator among other as follows: (1) Wages and salaries, (2) Incentives, (3) Benefits, and (4) Facilities.

Motivation is the impetus for a series of human behavior processes to achieve goals. Simultaneously, the elements contained in motivation include details of arousing, directing, maintaining, showing intensity, being continuous and purposeful. According to Hasibuan (2017), that employee motivation is influenced by or indicators to determine the level of work motivation in employees are (1) the need for achievement, (2) the need for affiliation, (3) the need for competence, and (4) the need for power.

\section{Results and Discussion}

Sub-structural Testing 1 Structural Equation: Y1 = py1x1X1 + py 1x2 X2 + y1E1, Simultaneous Testing Sub-structural 1, from processing sub-structural data 1. Using the SPSS program the ANOVA results are shown in table 1. 
Proceedings of the International Conference on Industrial Engineering and Operations Management Sao Paulo, Brazil, April 5 - 8, 2021

Table 1 Sub Structural Anova 1

\begin{tabular}{|l|l|l|l|l|l|l|}
\hline \multicolumn{2}{|l|}{ Model } & Sum of Squares & df & Mean Square & F & Sig. \\
\hline 1 & Regression & 51.619 & 2 & 25.810 & 8.534 & $.000^{\text {a }}$ \\
& Residual & 435.496 & 144 & 3.024 & & \\
& Total & 487.116 & 146 & & & \\
\hline
\end{tabular}

Source: Data Processing Results, 2019

The statistical hypothesis is formulated as follows: H0: py1x1 = py1x2=0, H1: py1x1 = py1x2 $\neq 0$. H0: Knowledge and compensation simultaneously do not affect $\mathrm{H} 1$ Motivation: Knowledge and Compensation simultaneously affect Motivation $\mathrm{n}$ If the value of $\mathrm{sig} \geq 0,05$, then $\mathrm{H} 0$ is accepted and $\mathrm{H} 1$ is rejected, and if the sig value $<0.05$, then $\mathrm{H} 0$ is rejected and $\mathrm{H} 1$ is accepted. Based on table 1 , an F value of 8.534 is obtained with a probability value $(\operatorname{sig})=0,000$. Because the sig value $<0.05$, then $\mathrm{H} 0$ is rejected, and $\mathrm{H} 1$ is accepted. Manually to get the value of F can be calculated using the formula F calculate as follows: $F=(n-1) R 2 y x k / k(1-R 2 y x k)=(147-2-1) 0.106 / 2(1-0.106)=8.537$ Based on the table 4.18 obtained an F-calculated value of 8.534 so that F-count $>$ F table $(8.534>3.06)$ then $\mathrm{H} 0$ is rejected and $\mathrm{H} 1$ is accepted. The conclusion is that knowledge and compensation simultaneously have a significant effect on motivation so that individual testing can be carried out or continued. Individual tests are shown in Table 2.

Table 2 Coefficients Sub structural 1

\begin{tabular}{|c|c|c|c|c|c|c|}
\hline \multicolumn{7}{|c|}{ Coefficients } \\
\hline & & \multicolumn{2}{|c|}{$\begin{array}{l}\text { Unstandardized } \\
\text { Coefficients }\end{array}$} & \multirow{2}{*}{$\begin{array}{l}\text { Standardized } \\
\text { Coefficients } \\
\text { Beta }\end{array}$} & \multirow[b]{2}{*}{$\mathrm{t}$} & \multirow[b]{2}{*}{ Sig. } \\
\hline \multicolumn{2}{|c|}{ Model } & B & Std. Error & & & \\
\hline \multirow[t]{3}{*}{1} & (Constant) & 10.048 & 1.530 & & 6.565 & .000 \\
\hline & Knowledge & .129 & .051 & .205 & 2.538 & .012 \\
\hline & Compensation & .239 & .091 & .212 & 2.622 & .010 \\
\hline \multicolumn{3}{|c|}{ a. Dependent Variable: Motivation } & & & & \\
\hline
\end{tabular}

Knowledge (X1) on Motivation (Y1)

The research hypothesis that will test is formulated into statistics: H0: pY1X1 = 0 H1: pY1X1>0. The hypothesis in the form of sentences is as follows: H0: Knowledge does not influence H1 Motivation: Knowledge of influence on motivation If the value of sig $\geq 0.05$, then $\mathrm{H} 0$ is accepted and $\mathrm{H} 1$ is rejected and if sig $<0.05 \mathrm{H} 0$ is rejected and $\mathrm{H} 1$ is accepted. Based on 2, it was obtained t value of 2.538 with a sig value of $0.012<0.05$, then $\mathrm{H} 0$ was rejected, and $\mathrm{H} 1$ was accepted, so knowledge had a significant effect on motivation. Based on table $2 \mathrm{t}$ with $\mathrm{df}=147-2-1=144 \mathrm{and}$ a $=0.05$ obtained a value of 1.656 so that $\mathrm{t}$ count $>\mathrm{t}$ table $(2.538>1.656)$, then $\mathrm{H} 0$ is rejected and $\mathrm{H} 1$ is accepted, so Knowledge influences Motivation. The coefficient of 0.205 means that if the compensation variable is fixed, but the value of knowledge is increased by 1 , motivation will increase by 0.205 . The coefficient value is positive, so knowledge has a positive effect on motivation.

Compensation (X2) for Motivation (Y1)

The research hypothesis that will be tested is formulated into statistics as follows: H0: pY1X2 = $0 \mathrm{H} 1: \mathrm{pY} 1 \mathrm{X} 2>0$ Hypothesis in the form of a sentence is as follows: H0: Compensation does not affect Motivation H1: Compensation of influence on motivation If the value of $\operatorname{sig} \geq 0.05$, then $\mathrm{H} 0$ is accepted and $\mathrm{H} 1$ is rejected. If sig $<0.05, \mathrm{H} 0 \mathrm{is} \mathrm{rejected,}$ and $\mathrm{H} 1$ is accepted. Based on table 2, obtained t value of 2.622 with a sig value of $0.010<0.05$ then $\mathrm{H} 0$ is rejected, and $\mathrm{H} 1$ is accepted, so compensation has a significant effect on motivation. Based on table $2 \mathrm{t}$ with $\mathrm{df}=147-2-1=$ 144 and $\mathrm{a}=0.05$, the value of 1.656 is obtained so that $\mathrm{t}$ arithmetic $<\mathrm{t}$ table $(2.662<1.656)$, then H0 is accepted and $\mathrm{H} 1$ is rejected, so compensation has no effect on motivation. A coefficient of 0.212 means that if the variable of knowledge is fixed, but the value of compensation is increased by one, motivation will increase by 0.212 . The coefficient value is positive, so compensation has a positive effect on motivation.

Structural Equations Sub-structural 1 
Proceedings of the International Conference on Industrial Engineering and Operations Management Sao Paulo, Brazil, April 5 - 8, 2021

The determinant coefficient R2 is used to determine how much the percentage of the influence of the independent variable together on the dependent variable. The magnitude of the determinant coefficient of R-square or R2 seen in table 3 is $0.106=10.6 \%$. So, variations that occur in the dependent variable of $10.6 \%$ can be explained together with the independent variables. So that it can be calculated the influence of other variables not examined, namely: pyle $1=$ $1-0.106=0.894=89.4 \%$ or $=\sqrt{ } 1-\mathrm{R}$ Square $=\sqrt{ }(1-0.106)=0.946$

Table 3 Model summary Sub structural 1

\begin{tabular}{|c|c|c|c|c|}
\hline \multicolumn{5}{|c|}{ Model Summary } \\
\hline Model & $\mathrm{R}$ & R Square & $\begin{array}{l}\text { Adjusted } \\
\text { R Square }\end{array}$ & $\begin{array}{l}\text { Std. Error of } \\
\text { the Estimate }\end{array}$ \\
\hline 1 & $.326^{\mathrm{a}}$ & .106 & .094 & 1.739 \\
\hline
\end{tabular}

Source: data processing result, 2019

From sub-structural data processing 2 using SPSS, the results of ANOVA are shown in table 4

Table 4. Anova Sub structural 2

\begin{tabular}{|c|c|c|c|c|c|c|}
\hline \multicolumn{7}{|c|}{ ANOVA $^{\mathrm{b}}$} \\
\hline \multicolumn{2}{|c|}{ Model } & Sum of Squares & Df & Mean Square & $\mathrm{F}$ & Sig. \\
\hline \multirow[t]{3}{*}{1} & Regression & 458.186 & 3 & 152.729 & 114.658 & $.000^{\mathrm{a}}$ \\
\hline & Residual & 190.480 & 143 & 1.332 & & \\
\hline & Total & 648.667 & 146 & & & \\
\hline \multicolumn{6}{|c|}{ a. Predictors: (Constant), Motivation, Compensation, Knowledge } & \\
\hline \multicolumn{6}{|c|}{ b. Dependent Variable: Documentation } & \\
\hline
\end{tabular}

Source: data processing result, 2019

The overall test is shown in table 4 . The statistical hypothesis is formulated as follows: H0: py $2 x 1=p y 2 x 2=p y 2 y 1$ $=0 \mathrm{H} 1$ : py $2 \times 1=$ py $2 \times 2=$ py $2 \mathrm{y} 1 \neq 0 \mathrm{H} 0$ : Knowledge, Compensation and motivation simultaneously have no effect on $\mathrm{H} 1$ documentation: Knowledge, Compensation and motivation simultaneously influence documentation. If the value of sig $\geq 0.05$, then $\mathrm{H} 0$ is accepted, and $\mathrm{H} 1$ is rejected. If the value of sig $<0.05$, then $\mathrm{H} 0$ is rejected, and $\mathrm{H} 1$ is accepted. Based on table 4 , the $\mathrm{F}$ value is 114.658 with the probability value (sig) $=0.000$. Because the sig value $<0.05$, then H0rejected and $\mathrm{H} 1$ accepted. Manually to get the value of $\mathrm{F}$ can be calculated using the formula $\mathrm{F}$ calculate as follows: $\mathrm{F}=(\mathrm{n}-1) \mathrm{R} 2 \mathrm{yxk} / \mathrm{k}(1-\mathrm{R} 2 \mathrm{yxk})=(147-3-1) 0.706 / 3(1-0.706)=114.465$ Based on the table 4.21 obtained an F-count value of so F count $>\mathrm{F}$ table $(2,051, \mathrm{E} 3>3.06)$ then $\mathrm{H} 0$ is rejected and $\mathrm{H} 1$ is accepted. So, the conclusion is Knowledge Compensation, and Motivation simultaneously has a significant effect on Documentation, and therefore individual testing can be carried out or continued.

Simultaneous Sub-structural Testing 2

Individual tests are shown in Table 5

Table 5 Coefficients Sub structural 2

\begin{tabular}{|c|c|c|c|c|c|c|}
\hline \multicolumn{7}{|c|}{ Coefficients } \\
\hline & & \multicolumn{2}{|c|}{ Unstandardized Coefficients } & \multirow{2}{*}{\begin{tabular}{|l|} 
Standardized Coefficients \\
Beta \\
\end{tabular}} & \multirow[b]{2}{*}{$\mathrm{T}$} & \multirow[b]{2}{*}{ Sig. } \\
\hline \multicolumn{2}{|c|}{ Model } & B & Std. Error & & & \\
\hline \multirow[t]{4}{*}{1} & (Constant) & 1.461 & 1.158 & & 1.262 & .209 \\
\hline & Knowledge & .470 & .034 & .647 & 13.628 & .000 \\
\hline & Compensation & .249 & .062 & .191 & 4.025 & .000 \\
\hline & Motivation & .322 & .055 & .279 & 5.830 & .000 \\
\hline & endent Variab & Docum & & & & \\
\hline
\end{tabular}

Source: Data processing result, 2019

Knowledge (X1) of documentation (Y2) 
The research hypothesis to be tested is formulated into statistics as follows: H0: py $2 \times 1=0$ H1: py $2 x 1>0$ Hypothesis in the form of a sentence is as follows: H0: Knowledge does not influence documentation of H1: Knowledge of influence on documentation If the value of sig $\geq 0.05$, then $\mathrm{H} 0$ is accepted and $\mathrm{H} 1$ is rejected and if $\operatorname{sig}<0,05 \mathrm{H} 0$ is rejected and $\mathrm{H} 1$ is accepted. Based on table 5, the $t$ value of 13.662 was obtained with a sig value of $0.000<0.05$, then $\mathrm{H} 0$ was rejected, and $\mathrm{H} 1$ was accepted, so knowledge has a significant effect on documentation. Based on table $4 \mathrm{t}$ with $\mathrm{df}=147-3-1=143$ and $\mathrm{a}=0.05$, the value of 1.656 is obtained so that $\mathrm{t}$ arithmetic $>\mathrm{t}$ table $(13.662>1.656)$, then $\mathrm{HO}$ is rejected and H1 is accepted, so knowledge influences the Documentation coefficient of 0.647 which means if the compensation variable and the Motivation is fixed. Still, the value of experience is increased by 1 . Then documentation will increase by 0.647 . The coefficient value is positive, so knowledge has a positive effect on documentation.

Compensation (X2) for documentation (Y2)

The research hypothesis that will be tested is formulated into statistics as follows: H0: py $2 \times 2=0 \mathrm{H} 1$ : py $2 \times 2>0$ The hypothesis in the form of sentences is as follows: H0: Compensation does not affect documentation H1: Compensation of influence on documentation If the value of sig $\geq 0.05$, then $\mathrm{H} 0$ is accepted and $\mathrm{H} 1$ is rejected. If $\operatorname{sig}<0.05, \mathrm{H} 0$ is rejected, and $\mathrm{H} 1$ is accepted. Based on table 5 , the value of $\mathrm{t}$ is 4.025 with a sig value of $0.000<0.05$, then $\mathrm{H} 0$ is rejected, and $\mathrm{H} 1$ is accepted, so compensation has a significant effect on documentation. Based on table $4 \mathrm{t}$ with $\mathrm{df}=$ $147-3-1=143$ and $\mathrm{a}=0.05$, the value of 1.656 is obtained so that $\mathrm{t}$ arithmetic $>\mathrm{t}$ table (4.025>1.656), then $\mathrm{H} 0$ is rejected and $\mathrm{H} 1$ is accepted, so compensation affects documentation. A coefficient of 0.191 means that if the variable of knowledge and Motivation has a fixed value, but the value of compensation is increased by 1, documentation will increase by 0.191 . The coefficient value is positive, so compensation has a positive effect on documentation.

Motivation (Y1) towards documentation (Y2)

The research hypothesis will be tested is formulated as statistics as follows: H0: pY2Y1 $=0 \mathrm{H} 1: \mathrm{pY} 2 \mathrm{Y} 1>0$. Hypothesis in the form of sentences is as follows: H0: Motivation does not influence H1 documentation: Motivation of influence on documentation If the value of sig $\geq 0.05$, then $\mathrm{H} 0$ is accepted and $\mathrm{H} 1$ is rejected. If $\operatorname{sig}<0.05, \mathrm{H} 0$ is rejected, and $\mathrm{H} 1$ is accepted. Based on table 5, the value of $\mathrm{t}$ is 29.405 with a sig value of $0.000<0.05$, then $\mathrm{H} 0$ is rejected, and $\mathrm{H} 1$ is accepted, so knowledge has a significant effect on documentation. Based on table $4 \mathrm{t}$ with $\mathrm{df}=147-3-1=143$ and $\mathrm{a}=0.05$, the value of 1.656 is obtained so that $\mathrm{t}$ arithmetic $>\mathrm{t}$ table $(29.045>1.656)$, then $\mathrm{H} 0$ is rejected and $\mathrm{H} 1$ is accepted. Motivation influences the Documentation coefficient of 0.667 , meaning if the knowledge and compensation variables are fixed but the motivational value is increased by 1 , then documentation will increase by 0.667 .

The coefficient value is positive, so Motivation has a positive effect on documentation. Sub-structural Structural Equation 2 is the determinant coefficient R2 used to determine how much percentage of the contribution of the influence of the independent variables together on the dependent variable. The magnitude of the determinant coefficient of R-square or R2 seen in table 6 is $0.706=70.6 \%$. So, variations occur in the dependent variable of $70.6 \%$. It can be explained together with the independent variables. So that it can be calculated the influence of other variables not examined, namely: py2e $2=1-0.706=0.294=29.4 \%$ or $=\sqrt{ } 1-$ R Square $=\sqrt{ }(1-0.706)=0.542$ Table 6 Substructural Model summary 2.

Table 6 Model summary Sub Structural 2

\begin{tabular}{|l|l|l|l|l|}
\hline \multicolumn{3}{|l|}{ Model Summary } \\
\hline Model & $\mathrm{R}$ & R Square & Adjusted R Square & $\begin{array}{l}\text { Std. Error of } \\
\text { the Estimate }\end{array}$ \\
\hline 1 & $.840^{\mathrm{a}}$ & .706 & .700 & 1.154 \\
\hline \multicolumn{4}{|l|}{ a. Predictors: (Constant), Motivation, Compensation, Knowledge } \\
\hline
\end{tabular}

Source: Data Processing Results, 2019

Analysis of mediating or intervening variables is the causal step strategy (the effect of knowledge on documentation through motivation) Knowledge regression analysis (X1) on motivation (Y1). The coefficient table 2 of the output can be seen the coefficient $\mathrm{a}$, is equal to $0.129(\beta \mathrm{a}=0.205)$, with ta $=2.538$ and a significance of $0.012<0.05$. Thus, $\mathrm{X} 1$ significantly influences $\mathrm{Y} 1(\mathrm{a} \neq 0)$. Knowledge regression analysis $(\mathrm{X} 1)$ on documentation $(\mathrm{Y} 2)$. The coefficient $\mathrm{b}$ based on table 5 of the output can be seen the value of the coefficient $b$ is equal to $0.470(\beta b=0.647)$, with tb $=$ 13.662 and the significance of $0.000<0.05$. Thus, $\mathrm{X} 1$ significantly influences $\mathrm{Y} 2(\mathrm{t} \neq 0)$. Knowledge regression analysis (X1) to motivation (Y1) to documentation (Y2). Based on table 5 of the outputs, the coefficient a is equal to 
Proceedings of the International Conference on Industrial Engineering and Operations Management Sao Paulo, Brazil, April 5 - 8, 2021

$0.470(\beta \mathrm{a}=0.647)$. The value of ta is 13.662 , the significance of $\mathrm{P}<0.05$, and the coefficient $\mathrm{c}$ is $0.322(\beta \mathrm{c}=0.279)$, and the value of it is 5.830, the importance of $\mathrm{P}<0$ Thus, $\mathrm{X} 1$ significantly influences $\mathrm{Y} 2$ through $\mathrm{Y} 1(\mathrm{t} \neq 0)$. In conclusion: because the coefficients $\mathrm{a}, \mathrm{b}$, and $\mathrm{c}$ are significant, it is sufficient to indicate mediation where the knowledge variable (X1) can influence the documentation variable directly (Y2) or indirectly by involving the motivational variable $(\mathrm{Y} 1)$.

Causal step strategy (Effect of compensation on performance through motivation) Analysis of compensation regression (X2) on motivation (Y1) based on table 2 of the output can be seen the coefficient a value is 0.239 ( $\beta \mathrm{a}=$ 0.212 ), with ta $=2.622$ and significance $0.010<0.05$. Thus, $\mathrm{X} 2$ compensation significantly influences motivation $\mathrm{Y} 1$ $(\mathrm{a} \neq 0$ ). Compression regression analysis (X2) for documentation (Y2) based on table 5 of the outputs can be seen the coefficient value $\mathrm{b}$ is 0.249 ( $\beta \mathrm{b}=0.191$ ), with $\mathrm{tb}=4.025$ and the significance of $\mathrm{P}<0.05$. Thus, $\mathrm{X} 2$ compensation significantly influences documentation $\mathrm{Y} 2(\mathrm{~b} \neq 0)$ Analysis of compensation regression $(\mathrm{X} 2)$ on motivation $(\mathrm{Y} 1)$ on documentation (Y2). Based on table 5 of the outputs the coefficient a is equal to 0.239 ( $\beta \mathrm{a}=0.212$ ), with ta $=2.622$ and significance $0.010<0.050 .239(\beta \mathrm{a}=0.212)$, with ta $=2.622$ and significance $0.010<0.05$ Thus compensation (X2) significantly influences documentation (Y2) through motivation (Y1) $(t \neq 0)$. In conclusion: because the coefficients $\mathrm{a}, \mathrm{b}$ and $\mathrm{c}$ are significant, it is sufficient to indicate mediation where the compensation variable (X2) is able to directly influence documentation (Y2) or indirectly by involving the motivational variable (Y1)Effect calculation consists of Direct Effect (Direct Effect or DE) is the influence of knowledge variables on motivation X1 $\Rightarrow \mathrm{Y} 1=0.205$ with $\mathrm{P}=0.012$, The effect of compensation variables on motivation $\mathrm{X} 2=>\mathrm{Y} 1=0.212$ with $\mathrm{P}=0.010$, The effect of motivation variables on documentation $\mathrm{Y} 1 \Rightarrow \mathrm{Y} 2=0.279$ with $\mathrm{P}=0,000$, Effect of knowledge variable on documentation $\mathrm{X} 1 \Rightarrow \mathrm{Y} 2=0.647$ with $\mathrm{P}=0,000$, Effect of compensation variable on documentation $\mathrm{X} 2 \Rightarrow \mathrm{Y} 2=$ 0,191 with $\mathrm{P}=0,000$, Indirect Effect (Indirect effect or IE) is the influence of knowledge variables on documentation through motivation $\mathrm{X} 1=>\mathrm{Y} 1=>\mathrm{Y} 2=(0.205 \times 0.279)=0.057$, Effect of compensation variables on documentation through motivation $\mathrm{X} 2 \Rightarrow \mathrm{Y} 1 \Rightarrow \mathrm{Y} 2=(0.212 \times 0.279)=0.059$. Effect of Total (Total Effect) is the influence of knowledge variables on documentation through motivation $\mathrm{X} 1=>\mathrm{Y} 1 \Rightarrow \mathrm{Y} 2=(0.647+0.057)=0.704$, The effect of compensation variables on documentation through motivation $\mathrm{X} 2 \Rightarrow \mathrm{Y} 1 \Rightarrow \mathrm{Y} 2=(0.191+0.059))=0.250$, Based on the results of the above calculation it is known that: The value of the direct influence of knowledge on documentation is greater than the indirect effect of knowledge on documentation through motivation. The value of the direct effect of compensation on documentation is greater than the indirect effect of compensation on documentation through motivation.

Hypothesis test stage that is direct there is a significant influence of knowledge (X1) on motivation (Y1) from the analysis obtained a significant value of $0.012<0.05$. Directly there is a significant effect of compensation (X2) on motivation (Y1) from the analysis obtained a significant value of $0.010<0.05$. Directly there is a significant influence of knowledge (X1) on Documentation (Y2) from the analysis obtained a significant value of $0,000<0.05$. There is a significant direct effect of compensation (X2) on Documentation (Y2) from the analysis obtained a significant value of $0,000<0.05$. Directly there is a significant influence of Motivation (Y1) on Documentation (Y1) from the analysis obtained a significant value of motivation (Y1) of $0,000<0.05$. The direct effect of knowledge (X1) on Documentation (Y2) is 0.647 , while the indirect effect of knowledge (X1) through motivation (Y1) on Documentation (Y2) is: 0.647 x $0.279=0.181$. Then the total effect given is the direct effect plus the indirect effect, namely: $0.647+0.181=0.828$. The direct effect of compensation (X2) on Documentation (Y2) was 0.191 , while the indirect effect of compensation (X2) through motivation (Y1) on Documentation (Y2) was: $0.191 \times 0.279=0.053$. Then the total effect given is the direct effect plus the indirect effect, namely: $0.191+0.053=0.244$.

\section{Conclusion}

1. Knowledge has a positive and significant effect on nurses' motivation at Mamuju Regional General Hospital, meaning that if knowledge increases, stimulation also increases and vice versa. So that compensation has a positive and significant effect on nurses' basis at Mamuju Regional General Hospital. This means that repayment is increased, the motivation also increases, and vice versa.

2. Knowledge has a positive and significant effect on documentation at Mamuju Regional General Hospital. It means that if knowledge increases, documentation will also be complete and vice versa.

3. Compensation has a positive and significant effect on documentation at Mamuju Regional General Hospital.

4. Motivation has a positive and significant effect on documentation at Mamuju Regional General Hospital.

5. Knowledge has a positive and significant influence on documentation and indirect effect through motivation at the Mamuju Regional General Hospital. 
Proceedings of the International Conference on Industrial Engineering and Operations Management Sao Paulo, Brazil, April 5 - 8, 2021

6. Compensation has a positive effectand significant towards documentation and indirect influence through motivation at the Mamuju Regional General Hospital.

\section{References}

Abdullah, R. (2018a). Aplikasi Manajemen Rumah Sakit. Badan Penerbit Universitas Negeri Makassar.

Abdullah, R. (2018b). Metode Penelitian Dalam Aspek Kesehatan. Badan Penerbit Universitas Negeri Makassar.

Ahmad, H. 'Aziz. (2017). Hubungan Antara Pendidikan Dan Pengetahuan Perawat Dengan Kelengkapan Pendokumentasian Askep. 269, 1-10.

Andi Ikhsan Kadir. (2014). Profesional Perawat Rumah Sakit. Zifatama Publisher.

Diansyah, T. S. (2014). Pengaruh Pelatihan dan Kompensasi Terhadap Kinerja Karyawan dengan Motivasi sebagai Variabel intervening pada Mikro lajur Cluster Jakarta2 PT Bank Cimb Niaga Tbk.

Hamel, K. H. P. F. J. M. R. R. S. (2014). Hubungan motivasi perawat dengan pelaksanaan dokumentasi asuhan keperawatan di instalasi rawat inap c RSUP prof. Dr. R. D. Kandou manado.

Juliandiny, T. (2016). Kompensasi Serta Motivasi Kerja Pada Kinerja Keperawatan Kontrak Rumah Sakit Umum Subang. 1(2), 81-90.

Kurnia, R. J. (2016). Pengaruh Kompensasi Danmotivasi Kerja Terhadap Kinerja Karyawan Rumah Sakit Condong Catur Yogyakarta.

Marlian, R. S. (2014). Pengaruh motivasi dan kemampuan terhadap pendokumentasian asuhan keperawatan di instalasi rawat inap rsud cibabat.

Marlian, R. S., \& Dadang Kusnadi. (2014). Pengaruh Motivasi dan Kemampuan Terhadap Pendokumentasian Asuhan Keperawatan. 38, 1-8.

Mu'adi, S., Maksum, A., Hakim, M. L., \& Umanailo, M. C. B. (2020). Transfer of function agricultural land. Proceedings of the International Conference on Industrial Engineering and Operations Management, 0(March), $2568-2574$.

Mubaroq, R. A., \& Z. (2017). Mubaroq, R. A., \& Zulkarnaen, Pengaruh Kompensasi Terhadap Motivasi Kerja Karyawan.

Natalia Buntu Sarira. (2015). Pengaruh kompensasi terhadap motivasi kerja karyawan pt. Insani baraperkasa di samarinda. 3(4), 951-965.

Nawawi, M., Ali, A., Irawan, B., Ahmad, B., Mukramin, S., Marsuki, N. R., Umanailo, M. C. B., \& Kaya, I. R. G. (2020). The village kalesang program as a poverty alleviation community. International Journal of Scientific and Technology Research, 9(3), 3103-3107.

Nugrahandini, E. (2015). Hubungan pengetahuan dan sikap perawat dengan motivasi pelaksanaan model praktik keperawatan profesional di rumah sakit jogja kota yogyakarta.

Nugroho, D. C. P. (2012). Hubungan Tingkat Pengetahuan Dengan Motivasi Mahasiswa Membeli Musik Bajakan (Studi Kasus Pada Mahasiswa Fakultas Dakwah Dan Ilmu Komunikasi Universitas Islam Negeri Sultan Syarif Kasim.

Nuraini, N., Riadi, A., Umanailo, M. C. B., Rusdi, M., Badu, T. K., Suryani, S., Irsan, I., Ismail, I., Pulhehe, S., \& Hentihu, V. R. (2019). Political Policy for the development of Education. International Journal of Scientific \& Technology Research, 8(10).

Nurul Nuryani, D. D. S. (2013). Hubungan Pengetahuan Perawat Dengan Kelengkapan Dokumentasi Asuhan keperawatan DIRSUD Dr.Soekardjo Kota Tasikmalaya,. 001, 5-9.

Pribadi, A. (2009). Analisis Pengaruh Faktor Pengetahuan, Motivasi, Dan Persepsi Perawat Tentang Supervisi Kepala Ruang Terhadap Pelaksanaan Dokumentasi Asuhan Keperawatan Di Ruang Rawat Inap Rsud Kelet Provinsi Jawa Tengah Di Jepara.

Risti, K. N., \& Isnaeni, F. N. (2017). Hubungan Motivasi Diri dan Pengetahuan Gizi terhadap Kepatuhan Diet DM pada Pasien Diabetes Mellitus Tipe II. 10-35.

Rosa, S. (2017). Hubungan motivasi perawat dengan pelaksanaan dokumentasi pengkajian di ruang bogenvile RSUD mgr. Gabriel manek, svd Atambua.

Shara, A. C., Aditya, G., \& Benyamin, B. (2014). Hubungan antara pengetahuan terhadap motivasi dokter gigi muda dalam kontrol infeksi. 2, 42-47.

Sugiyati, S. (2013). Hubungan Pengetahuan Perawat Dalam Dokumentasi Keperawatan Dengan Pelaksanaannya Di Rawat Inap Rsi Kendal.

Tety Rachmawati, T. (2002). Pengaruh Dukungan Sosial Dan Pengetahuan Tentang Penyakit Tb Terhadap Motlvasl Untuk Sembuh Penderita Tuberkulosis Paru Yang Berobat Dl Puskesmas. 1.

Umanailo, M. C. B. (2019). Structure of Social Change in Industrial Society. Proceedings of the International 
Conference on Industrial Engineering and Operations Management Riyadh, 668-672.

Umanailo, M. C. B. (2020). The energy in the context of social. Proceedings of the International Conference on Industrial Engineering and Operations Management, 0(March), 2503-2508.

Wicaksono, A. (2018). Pengaruh Keadilan Kompensasi Terhadap Kepuasan Kerja Perawat Di Rsud Sultan Imanuddin Pangkalan Bun Kalimantan.

\section{Biographies}

Sultan is a student at Magister Program of Economic Science of STIE AMKOP, Indonesia. His areas of interest and research include social science and economic. He has published some articles in national journals.

Hasmin Tamsah is a lecturer at Magister Program of Economic Science of STIE AMKOP, Indonesia. His areas of interest and research include social science, political science, sociology, legal studies, and public administration. He has published some books and many articles in national and international journals. He is a reviewer and editor in some local and international journals.

Hasan Nongkeng is a lecturer at Economics Department of STIE AMKOP, Indonesia. His areas of interest and research include economic, management, management human resource. He has published some books and many articles in national and international journals.

Jumra is a lecturer and the head of the study program in at Department of Law at the Sekolah Tinggi Ilmu Hukum Pengayoman, Indonesia. Her areas of interest and research include social science, political science, sociology, legal studies.

Yusriadi Yusriadi is a lecturer at Public Administration Department of Sekolah Tinggi Ilmu Administrasi Puangrimaggalatung, Indonesia and chancellor on Sekolah Tinggi Ilmu Hukum Pengayoman. His areas of interest and research include social science, political science, sociology, legal studies, and public administration. He has published some books and many articles in national and international journals. He is a reviewer and editor in some local and international journals.

Loth Botahala permanent lecturer at the Tribuana Alor Foundation in the Chemistry Study Program of the Faculty of Mathematics and Natural Sciences, Tribuana University, Kalabahi 1 April 2011 until now. The position of Chair of the Chemistry Study Program of the Faculty of Mathematics and Natural Sciences, Tribuana Kalabahi University in 2014-2016, Deputy Chancellor III of Tribuana Kalabahi University in 2016-2020, Head of the Tribuana Kalabahi University library in 2020-2025. Functional Position in Basic Chemistry course on August 31, 2014. Educator Certificate in the field of Chemistry on October 30, 2017. Department of Industrial Engineering (Chemical Engineering Study Program), Faculty of Engineering, University of Makassar "45 Makassar (Bosowa Makassar University) on June 1, 2001. S-2 Chemistry at Hasanuddin University on November 14, 2013.

M Chairul Basrun Umanailo has worked as a Lecturer at Iqra Buru University since 2011 until now he is still active in the University's academic activities. has served as head of the Centre for Planning and Community Development Studies (PSP2M) since 2018. Completed his master's program at Sebelas Maret University in 2016, is currently still completing research on the conversion of agricultural land functions. 